\title{
Nakasone on the brink as US trade war threatens
}

\section{Tokyo}

JAPAN's Prime Minister Yasahiro Nakasone visits the United States this week having just suffered a humiliating defeat in the Diet over his plans to introduce a sales tax next year. Some commentators are already predicting that Nakasone may be forced to resign after the June summit but much may depend on the outcome of his trip to Washington.

At the end of last year Nakasone was riding the crest of a wave. After winning a landslide victory in the July election, the prime minister forged ahead with the break-up and privitization of the national railways, rewrote party rules and won himself another year in office, and committed Japan to participation in the US Strategic Defense Initiative. But in an attempt to drastically reform Japan's taxation system by introducing a sales tax Nakasone has slammed into a brick wall.

In December a committee of the ruling Liberal Democratic Party (LDP) drew up plans for tax reform that included cuts in income tax, abolition of a tax-free savings system and introduction of a sales tax similar to Europe's VAT (Value Added Tax). From the outset there were howls of protest about the sales tax, not only from the opposition and public but also from rank-and-file members of the LDP.

The opposition parties seized their opportunity and resolutely refused to debate the fiscal 1987 budget in the Diet until the sales tax was scrapped. The sales tax also became the major issue in recent local elections, where Nakasone's plan proved to be a severe liability for the LDP.

But it was in the Diet that Nakasone met defeat. After months of delay the LDP tried to bulldoze the budget through the lower house using sheer weight of numbers (the ruling party holds a clear majority). The opposition responded with a Japanese filibuster - the 'cow walk'. A series of no-confidence motions against key committee members and the finance minister were introduced. Then began a slow-motion voting process. Each member of the opposition walked at a painfully slow pace to the voting podium, stopping after each step to stretch their legs and roll their necks. Voting dragged on day and night as one motion after another was introduced. Finally, last Thursday the bleary-eyed ruling party relented. The sales tax bill was withdrawn and within hours the budget passed the lower house.

This defeat is a major blow for Nakasone, who dug his heels in, in the belief that it was his mission to rehabilitate the nation's finances through tax reform (the government is in debt by more than $\$ 1$ million million). In the end it was his
Washington trip that forced Nakasone to retreat.

With US-Japan trade relations in a state of crisis, Nakasone has to present the US with solid evidence that Japan is taking concrete measures to boost domestic demand. But detailed plans of a Y5 million million programme to stimulate the economy could not be drawn up without passage of the budget.

But Nakasone's public image has suffered and failure to ease US-Japan trade friction when in Washington would place him in a very precarious position. On the other hand, if Nakasone can turn his pally relationship with US president Ronald Reagan to advantage and smooth over some of the trade problems he could return home in a greatly strengthened position.

Nakasone aides are already talking of extending the present Diet session into the summer. After discussion with the opposition, the sales tax could be re-introduced in revised form under a different name, and Nakasone is probably the only LDP politician with the nerve to do it.

David Swinbanks

\section{Another UK lab forced to make cuts London}

The Freshwater Biological Association (FBA), an independent British body that conducts mainly basic research on the ecology of rivers and lakes, may have to shed between 25 and 30 jobs, of a total staff of 103. Two-thirds of FBA's annual income of $£ 2.5$ million comes as a grant-in-aid from the government's Natural Environmental Research Council (NERC), with the rest from private contracts. Salary increases in line with Civil Service guidelines, coupled with a reduction in real terms of NERC's contribution and a fall-off in commissioned contracts, mean that a budget deficit of more than $\$ 500,000$ is projected for next year, with the deficit for the current financial year standing at $\mathbf{£ 4 0 , 0 0 0 \text { . }}$

FBA argues that the basic character of its research is not conducive to success in attracting large numbers of private contracts and it feels it deserves more government support. A final decision on the question of the redundancies will be made next month. Professor Edward Deevey, graduate research curator and professor at the Florida State Museum, described the news as "horrifying". "The FBA has a long record of extreme eminence in historical environmental science. A very large number of people are going to be quite upset." Simon Hadlington

\section{Aqueous award London}

Professor Tadashi Inagami of Vanderbilt University, Nashville, Tennessee, has been awarded the third Spa Foundation Prize for his work on blood pressure regulators, particularly renin, angiotensin and atrial natriuretic factor. Worth $£ 120,000$, the prize was created in 1984 to celebrate the 400th anniversary of the commercial

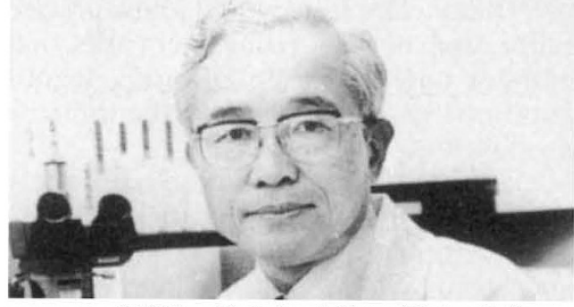

export of "The Original Spa Water" from the eponymous town in the Ardennes. The Spa prize, administered by Belgium's National Foundation for Scientific Research, is awarded for achievements in research, prevention or therapy of hypertension and cardiovascular disease. C.W

\section{Hungary for Eureka \\ London}

Hungary's Central Institute for Atmospheric Physics has applied to participate in Eureka, the European Economic Community's programme to foster high technology. The Hungarian move was announced by the West German ministry of research and technology, and the project the Hungarians wish to join is Eurotrac, which aims to monitor the spread of air pollutants in Europe. This is the first formal application from a Comecon country to participate in Eureka. V.R.

\section{Anglo-Dutch merger}

General Electric Company (GEC) of the United Kingdom and Philips of the Netherlands last week announced the merger of their medical equipment divisions to create the world's largest company specializing in medical diagnostic systems. The new company, which will have its headquarters in the United States, is expected to invest particularly heavily in the research and development of computer tomography and magnetic resonance systems.

The merger, between Philips medical systems division and GEC's Picker International subsidiary, will result in annual sales of about $\$ 2,000$ million, just ahead of the medical electronics divison of General Electric of the United States.

Philips' medical systems division employs 11,000 people with 8,500 based in Europe. Of Picker's workforce of $\mathbf{6 , 0 0 0}$, 4,000 are based in the United States. GEC will make an additional investment of up to $\$ 200$ million in the joint company to bring its share up to $\mathbf{5 0}$ per cent. The merger is expected to be completed before the end of the year. 